\title{
Phenolic Content of Sugarcane in Relation to Red Rot Disease
}

Following WALKER's ${ }^{1}$ demonstration of phenolic compounds as factors for resistance in coloured onions to smudge and neck rot diseases, many more workers have demonstrated the importance of such compounds in the resistance of plants to parasitic diseases. Observations by ABBOTT ${ }^{2}$ and PARTHASARATHI and VIJAYASARADHY ${ }^{3}$ indicated that the juice of sugarcane varieties resistant to red rot disease had higher phenolic content than that of the susceptible ones. In an attempt to study the nature of resistance in sugarcane to nodal infection by the red rot pathogen, Colletotrichum falcatum Went (Glomevella. tucumanensis (Speg.) ARX and MurLer), the phenolic contents in the node, internode and leaf-sheath of 4 susceptible (Co. 312, Co. 331, Co. 445 and C. 1181) and 2 moderately resistant varieties (Co. 285 and Co. 1070) were determined and the results are reported here.

The tissues of the 8 th node from top, between the point of attachment of the leaf-sheath and the growth ring; the leaf-sheath attached to the 8 th node $(10 \mathrm{~cm}$ length from the base) and the internode between the 8 th and 9 th node $(4 \mathrm{~cm}$ portion from the middle) of 5 canes of each variety were used for phenol extraction. Extracts were prepared by the method of ECHANDI and FERNANDEZ ${ }^{4}$. The phenol content of the extracts was estimated colorimetrically in chlorogenic acid equivalents, by adopting the Hoepfner-Vorsatz test described by ReEVE ${ }^{5}$. To $10 \mathrm{ml}$

Phenol content in the node, internode and leaf-sheath of sugarcane varieties

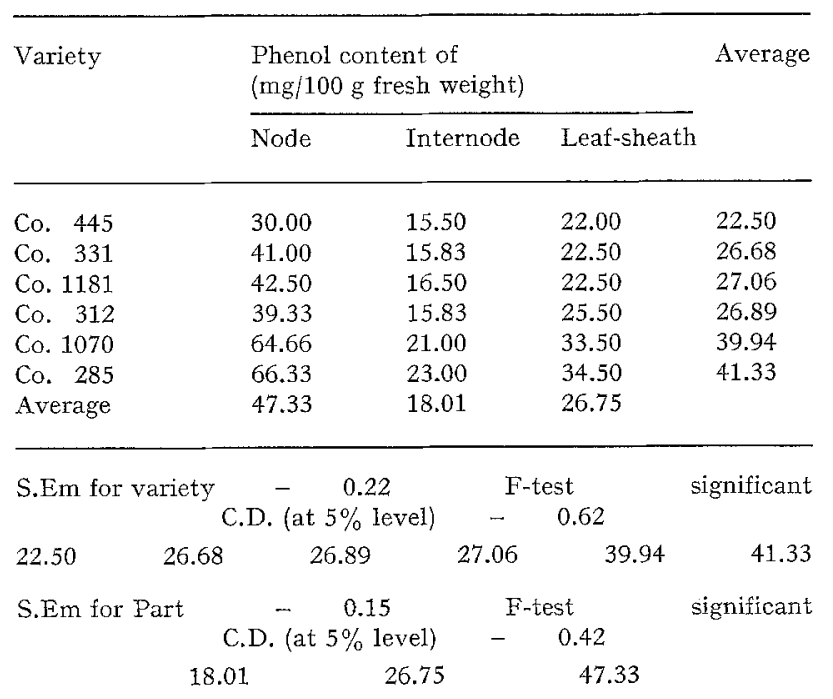

of the extract were added $2 \mathrm{ml}$ of $10 \%$ freshly prepared sodium nitrite, $2 \mathrm{ml}$ of $10 \%$ acetic acid and after $3 \mathrm{~min}$ $4 \mathrm{ml}$ of $2 \mathrm{~N}$ sodium hydroxide. The optical density of the solution was then measured in a Bausch and Lomb colorimeter, using a $420 \mathrm{~nm}$ filter. The concentration of phenols in the solution was calculated from a standard curve prepared by using the optical densities of different concentrations of pure chlorogenic acid in distilled water. The data are presented in the Table.

The results indicate that the phenolic contents in the node, internode and leaf-sheath of sugarcane varieties moderately resistant to red rot infection are higher than those of the susceptible ones. The nodal tissues of moderately resistant varieties contained $11 / 2$ times more phenols than the susceptible ones. Since the red rot fungus infects sugarcane chiefly through the tissues at the nodal region of the plant (BUTLER and HAFIZ KHAN ${ }^{6}$, $\mathrm{CHONA}^{7}$, and Steib and Chilton ${ }^{8}$ ), it is felt that the quantity of phenols in the nodal tissues can be used as an index for assessing the degree of resistance to infection by the pathogen and to eliminate the highly susceptible varieties. The phenolic content test is easy to conduct and can be employed in place of the cumbersome and time-consuming nodal inoculation test which is being done currently for the selection of red rot resistant sugarcane varieties.

Zusammenfassung. Hohe Konzentrationen an phenolischen Substanzen in Zuckerrohrpflanzen hemmen die durch den Parasiten Collectotrichum falcatum Went verursachte Pilzfäule.

K. I. Wilson ${ }^{9}$ and D. N. SRIVAstava ${ }^{10}$

Division of Mycology and Plant Pathology,

Indian Agricultural Research Institute,

New Delhi (India), 10 June 1970.

1 J. C. WALkER, J. agric. Res. 24, 1019 (1923).

2 E. V. AbbotT, Tech. Bull. US Dept. Agric. 647 (1938).

3 K. Parthasarathi and M. Vijayasaradhy, Curt. Sci. 27, 218 (1958).

4 E. Echandi and C. E. Fernandez, Phytopathology 52, 544 (1962).

s. R. M. ReEve, Stain Technol. 26, 91 (1951).

${ }^{6}$ E. J. Butler and A. Hafiz Khan, Mem. Dep. Agric. India bot. ser. 6, 151 (1913).

7 B. L. Chona, Ind. J. agric. Sci. 20, 363 (1950).

8 R. J. Steib and S. J. P. Chilton, Phytopathology 41, 522 (1951).

9 Plant Pathology Division, Agricultural College and Research Institute, Vellayani (Kerala, India).

10 Deputy Agricultural Commissioner, I.C.A.R., Krishi Bhavan, New Delhi (India).

\section{Effects of Ions and Gortisol on RNA Synthesis in Lysed Rat Liver Nuclei}

In previous papers we have shown that cortisol enhances RNA polymerase activity of isolated rat liver nuclei by increasing the template activity of the chromatin $\mathbf{1 , 2}$. In these and other reports, attention has been called to the importance of ionic conditions for RNA synthesis in in vitro systems ${ }^{3-6}$. In order to elucidate the mechanism by which cortisol controls the RNA synthesizing machinery of the cell nucleus, it seems necessary to investigate the ionic dependence of the hormonal effect and the nature of the product synthesized.

Male Wistar BR II rats (120-160 g) were used. The ${ }^{14} \mathrm{C}$-labelled nucleoside triphosphates were obtained from The Radiochemical Centre, Amersham; the non-labelled ribonucleoside triphosphates, creatine phosphate and 